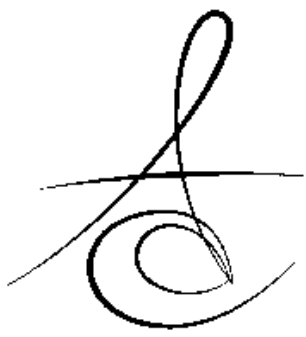

\title{
BİR DİŞ HEKİMLİĞİ FAKÜLTESİNE BAŞVURAN BİREYLERİN SİSTEMİK DURUMLARININ DEĞERLENDİRİLMESİ
}

\section{THE EVALUATION OF SYSTEMIC CONDITIONS OF A GROUP OF INDIVIDUALS WHO ATTENDED TO A DENTISTRY FACULTY}

Doç. Dr. Emin Murat CANGER*

Arş. Gör. Dt. Fatma AVCI

Araş. Gör. Dt. Şifa TATLI**

Makale Kodu/Article code: 3110

Makale Gönderilme tarihi: 04.11.2016

Kabul Tarihi: 16.12 .2016

\section{öz}

Amaç: Sistemik hastalıklar diş tedavilerinin hem yapılmasına engel olmakta hem de seyirlerini etkilemektedirler. Ayrıca pek çok sistemik hastalık ilk bulgusunu ağızda vermektedir. Bu nedenle diş hekimleri hem sistemik hastalıkları iyi bilmeli hem de bunları öğrenebilmek için anamneze büyük önem vermelidir. Bilgi düzeyi yüksek olan bir diş hekimi, sistemik hastalıkların ortaya çıkarılmasında yönlendirici de olabilir. Bu çalışmada, diş hekimliği fakültesine başvuran hastaların bir grubunun sistemik hastalık profilinin ortaya konması amaçlandı. Ayrıca, Kayseri ve çevresindeki illerde görev yapan diş hekimlerinin karşılaşabilecekleri sistemik hastalıklar ile ilgili farkındalıklarının arttırılması da hedeflendi.

Gereç ve Yöntem: Çalışmada 4032 hastaya ait anamnez formları değerlendirildi. Bu hastaların 2167'i $(\% 53,8)$ kadın, 1865'i $(\% 46,2)$ ise erkekti. 1291 $(\% 32,02)$ bireyde çeşitli sistemik hastalıkların var olduğu anlaşıldı.

Bulgular: En fazla görülen hastalık hipertansiyondu. $(\% 5,6)$ Bunu sırasıyla diyabet $(\% 4,2)$, kronik obstrüktif akciğer hastalığı (KOAH) $(\% 2,6)$, çeşitli psikiyatrik hastalıklar $(\% 2,4)$, tiroit bezi hastalıkları $(\% 2,3)$ ve viral hepatit $(\% 1,8)$, penisilin harici alerjiler $(\% 1,7)$, romatoit artrit $(\% 0,8)$, çeşitli kan hastalıkları $(\% 0,7)$, ve dermatolojik hastalıklar $(\% 0,4)$ takip ediyordu.

Sonuç: Hipertansiyonun, diyabetin, KOAH'ın, romatoid artiritin, psikiyatrik hastalıkların, tiroit bezi hastalıklarının kadınlarda daha fazla görüldüğü anlaşıldı. Erkeklerde en fazla rastlanan hastalığın ise viral hepatit olduğu görüldü.

Anahtar Kelimeler: Kronik hastalık, diş hekimliği, tıbbi kayıt, hikâye alma

\section{ABSTRACT}

Aim: The presence of systemic diseases do not cause delay in the initiation of dental treatment but also interfere with their course. Additionally the first signs of plenty of systemic diseases come to exist in mouth initially. Therefore dentist must pay attention to the anamnesis and must be intelligent about the systemic diseases. A dentist whose systemic diseases knowledge is high, may also play important role in discovering systemic diseases in patients who are not aware of them. In this study it was aimed to display the medical profile of a patient population who attended to the faculty of dentistry, and to instruct the dentists working in Kayseri and its enviroment about the systemic diseases they might face to.

Materials and Methods: The medical records of 4032 patients were evaluated. $2167(53,8 \%)$ of them were female and $1865(46,2 \%)$ were male. It was understood that 1291 (32,02\%) patients had systemic diseases.

Results: The most frequent disease was hypertension. (5,6\%) It was followed by diabetes $(4,2$ $\%)$, chronic obstructive respiratuary diseases $(2,6 \%)$, various psychiatric diseases $(2,4 \%)$, diseases of thyroid gland $(2,3 \%)$, viral hepatitis $(1,8 \%)$, alergies except peniciline $(1,7 \%)$, romatoid arthritis $(0,8 \%)$, various haematological system diseases $(0,7 \%)$, and dermatologic diseases $(0,4 \%)$.

Conclusion: It was understood that, while hypertension, diabetes, chronic obstructive respiratuary system diseases, various psychiatric diseases, diseases of thyroid gland were predominantly seen in women, viral hepatitis was more prevlant within men.

Keywords: Chronic diseases, medical records, dentistry, patient records 


\section{GİRİŞ}

Ağız sağlığı ile sistemik sağlığın arasında birebir bir ilişki olduğu göz ardı edilmemelidir. Diş hekiminin görevi, tıbbi açıdan olumsuz bir durum ortaya çıkarmadan güvenilir ve etkili bir dental tedavi yapmaktır. Bu nedenle tedavi için başvuran bireylerin sistemik sağlık durumlarının öğrenilmesi, bazen de ortaya çıkarılması, diş hekimlerinin temel sorumluluğudur. Bu amaçla gerektiğinde konsültasyon istenebilir. ${ }^{1,2}$ Tıbbın ayrılmaz bir parçası olan diş hekimliğinde hastaların değerlendirilmesinde tıbbi hikâye, yani anamnez, temel bir unsurdur. Anamnez, yalnız var olan şikâyetleri değil, eski hastalıkları, sistemik durumu, geçirilen ameliyatları ve ailesel hikâyeyi de içermelidir. Aile hikâyesinin alınması anamnezin etkili ve önemli bir unsurudur. Bu sayede hipertansiyon, diyabet, kanamaya yatkınlık, bazı kanserler ve obezite gibi kalıtımsal faktörlerin etkili olduğu kimi hastalıkların yakın akrabalarda varlığının öğrenilmesi, hastanın da bunlar açısından değerlendirilmesinde yol gösterici olur. ${ }^{3}$ Ayrıca vücut yapısı, konuşma şekli de hastanın potansiyel sağlık problemleri hakkında fikir sahibi olunmasına yarayabilir. 4

Sağlıklı bir insanda diş hekimliği müdahaleleri rahatlıkla yapılabilirken; kardiyovasküler sistem hastalığı, kontrolsüz diyabet, karaciğer hastalığı, kanama bozuklukları gibi bazı hastalıkları olan bireylerde tedavi sırasında çeşitli komplikasyonların ortaya çıkması olasılığı yüksektir. ${ }^{5} \mathrm{Bu}$ tür hastalar hastalıkların seyri, kullanılan ilaçlar ve tedavi sürecine etki edebilecek diğer bazı unsurlar bakımından daha kapsamlı incelenmelidir. Bu da daha derin bir tıp bilgisini gerektirmektedir. ${ }^{6} \mathrm{Bu}$ konu başarılı bir tedavi süreci ve hastanın işlemler esnasında zarar görmesini engellemek açısından son derece önemlidir.

Bu çalışmada, diş tedavi isteği ile Kayseri ve çevresi illerde yaşayan bir grup hastanın sahip oldukları sistemik hastalıkları belirlemek ve bölge diş hekimlerinin bilgi sahibi olmaları amaçlanmıştır.

\section{GEREÇ VE YÖNTEM}

Çalışmada 2015-2016 yılları arasında Erciyes Üniversitesi Diş Hekimliği Fakültesi Ağız, Diş ve Çene Radyolojisi Anabilim Dalına başvurarak muayenesi yapılmış olan hastalardan 4032 adedinin 4 ve 5 . sınıflara ait staj defterlerindeki anamnez bilgilerinden yararlanıldı. Bu çalışma için Erciyes Üniversitesi Klinik Araştırmalar Etik Kurulundan izin alındı. (Tarih:18-42016/ No. 2016-80) Hastalıklar aşağıdaki gibi sınıflandırıldı:

1. Kardiyo-vasküler sistem hastalıkları (hipertansiyon, kalp-damar hastalıkları ve diğer hastalıklar),

2. Endokrin sistem hastalıkları (diyabet, tiroid bezi hastalıkları, diğer hastalıklar),

3. Gastro-intestinal sistem hastalıkları (ülser, viral hepatit, karaciğer hastalıkları ve diğer hastalıklar),

4. Solunum sistem hastalıkları (astım, KOAH ve diğer hastalıklar),

5. Kan hastalıkları (anemi, lösemi ve diğer hastalıklar),

6. Romatolojik hastalıklar (romatoid artirit ve diğer hastalıklar),

7. Psikiatrik hastalıklar (panik atak ve diğer psikiyatrik hastalıklar),

8. Alerjik hastalılar (penisilin alerjisi ve diğer alerjiler),

9. Dermatolojik hastalıklar ve

10. Maligniteler (kolon kanseri, akciğer kanser, meme kanseri ve lenfoma).

Bu sınıflama yapılırken fakültemiz Ağız, Diş ve Çene Cerrahisi Hastanesin- de görev yapan iç hastalıkları uzmanından destek alındı.

Bireyler 18 yaş ve altı, 18-40 yaş arası, 41-65 yaş arası, 65 yaş ve üstü olarak dört grupta sınıflandırıldı.

Verilerin istatistiksel analizi SPSS paket programı ile yapıldı. (Deneme versiyonu, sürüm 24.0; SSPS Inc., Chicago, IL, USA). Tüm hastalıklar yaş grupları ve cinsiyete göre Pearson Ki kare $\left(\mathrm{X}^{2}\right)$ testinin Fisher's exact testi ile değerlendirildi. Sonuçlar $p<0,05$ için anlamlı olarak kabul edildi.

\section{BULGULAR}

Anamnez formu değerlendirilen 4032 kişinin 2168 'si $(\% 53,8)$ kadın, 1864'ü de $(\% 46,2)$ erkekti. Yaşları 3-86 arasında değişmekteydi. [Ortalama: 34,38 (kadın:32,27/erkek: 33,62)] Yaş gruplarına göre dağılıma bakıldığında; 482 kişinin $(\% 12,0) 18$ yaş ve altında, 2263 kişinin $(\% 56,1)$ 18-40 yaş arasında, 1135 kişinin (\%28,1) 41-65 yaş arasında, 152 kişinin de $(\% 3,72) 65$ yaş ve üstü olduğu görüldü.

2748 bireyde $(\% 67,98)$ sistemik hastalık yokken, 1284 bireyde $(\% 32,02)$ mevcuttu. Sistemik hastalıkların dağılımı Tablo 2'de verildi.

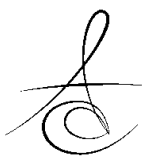


Tablo 1. Verilerin cinsiyetlere ve yaş gruplarına göre dağılımı

\begin{tabular}{|c|c|c|c|c|c|c|c|c|c|}
\hline CÍNSİYET & KADIN & ERKEK & TOPLAM & $\begin{array}{c}\text { YAS } \\
\text { GRUPLARI }\end{array}$ & $<\mathbf{1 8}$ & $\mathbf{1 8 - 4 0}$ & $\mathbf{4 1 - 6 5}$ & $>\mathbf{6 5}$ & TOPLAM \\
\hline $\mathbf{n}$ & 2167 & 1865 & $\mathbf{4 0 3 2}$ & $\mathbf{n}$ & 482 & 2263 & 1135 & 152 & $\mathbf{4 0 3 2}$ \\
\hline $\mathbf{\%}$ & 53,8 & 46,2 & $\mathbf{1 0 0}$ & $\mathbf{\%}$ & 12,0 & 56,1 & 28,1 & 3,8 & $\mathbf{1 0 0 , 0}$ \\
\hline
\end{tabular}

Tablo 2. Sistemik hastalıkların genel dağııımı

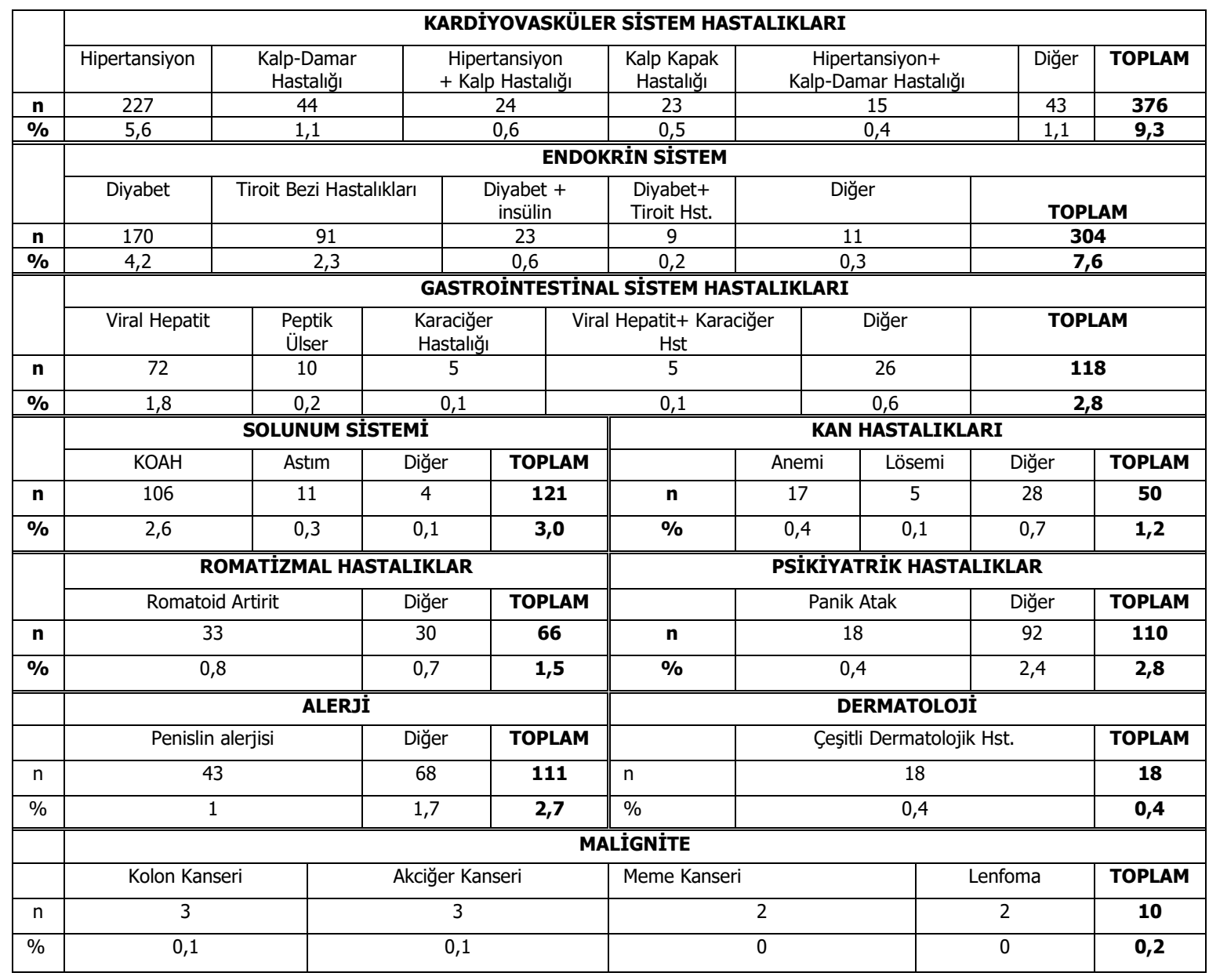

Sistemik hatalıkların dağııımına bakıldığında; endokrin sistem, solunum sistemi, kardiyovasküler sistem hastalıklarında cinsiyetler açısından istatistiksel açıdan anlamlı bir fark olduğu anlaşılmıştır. $(p=0,00)$ Romatoloji, gastrointestinal sistem, psikiyatri, alerji, kan hastalıkları ve malignite açısından ise anlamlı bir fark olmadığı görülmüştür. ( $p>0,05)$ (Tablo 3a ve Tablo 3b, Grafik 1)

Yaş gruplarına göre değerlendirilmede ise; kardiyovasküler sistem, endokrin sistem, gastrointestinal sistem, solunum sistem hastalıkları ile maligni- telere en çok 41-65 yaş grubunda, kan hastalıkları, dermatolojik hastalıklar, romatizmal hastalıklar, psikiyatrik hastalıklar ve alerjilere daha çok $18-40$ yaş aralığında, lenfomaya ise 65 yaş ve üstü grupta rastlandığı görüldü.

Endokrin sistem, kardiyovasküler sistem, gastrointestinal sistem, romatoloji, solunum sistemi ve malignitede yaş grupları açısından istatistiksel açıdan anlamlı fark olduğu $(p=0,00)$; alerji, psikiyatri, kan hastalıklarında ise anlamlı bir fark olmadığı anlaşıldı. ( $p>0,05)$ Yaş gruplarına göre hastalıkların dağılımı Tablo 4a, 4b ve Grafik 2'de verildi. 
Tablo 3a. Sistemik hastalıkların cinsiyetlere göre alt gruplarına dağıımları

\begin{tabular}{|c|c|c|c|c|c|c|c|c|c|c|}
\hline \multicolumn{11}{|c|}{ KARDİYOVASKÜLER SİSTEM } \\
\hline \multicolumn{3}{|c|}{ CİNSİYET } & HT* & KDH** & $\mathbf{K K H} * * *$ & Diğer & HT*+Diğer & HT+KDH** & Toplam & $\mathbf{P}$ \\
\hline \multirow{2}{*}{\multicolumn{2}{|c|}{ KADIN }} & $\mathrm{n}$ & 160 & 12 & 11 & 19 & 14 & 3 & 219 & \multirow{4}{*}{$=0.00$} \\
\hline & & $\%$ & 3,94 & 0,30 & 0,25 & 0,48 & 0,35 & 0,08 & 5,38 & \\
\hline \multirow{2}{*}{\multicolumn{2}{|c|}{ ERKEK }} & $\mathrm{n}$ & 69 & 32 & 11 & 24 & 9 & 12 & 157 & \\
\hline & & $\%$ & 1.68 & 0,80 & 0,25 & 0,62 & 0,25 & 0,32 & 3.92 & \\
\hline \multicolumn{11}{|c|}{ ENDOKRİN SİSTEM } \\
\hline \multicolumn{3}{|c|}{ CİNSİYET } & DM\# & $\begin{array}{c}\text { Tiroid } \\
\text { Bezi H. }\end{array}$ & $\begin{array}{c}\text { DM+ } \\
\text { İnsülin }\end{array}$ & $\begin{array}{c}\text { DM+Tiroid } \\
\text { Bezi }\end{array}$ & Diğer & TOPLAM & \multicolumn{2}{|c|}{$\mathbf{P}$} \\
\hline \multirow{2}{*}{\multicolumn{2}{|c|}{ KADIN }} & $\mathbf{n}$ & 98 & 75 & 8 & 3 & 7 & 191 & \multirow{4}{*}{\multicolumn{2}{|c|}{$=0.00$}} \\
\hline & & $\%$ & 2.42 & 1,89 & 0,20 & 0,06 & 0.19 & 4,76 & & \\
\hline \multirow{2}{*}{\multicolumn{2}{|c|}{ ERKEK }} & $\mathbf{n}$ & 72 & 16 & 15 & 6 & 4 & 113 & & \\
\hline & & $\%$ & 1.78 & 0,41 & 0,40 & 0,14 & 0,11 & 2,84 & & \\
\hline \multicolumn{11}{|c|}{ GASTROİNTESTİNAL SİSTEM } \\
\hline \multicolumn{3}{|c|}{ CINNSIYYET } & $\begin{array}{l}\text { Viral } \\
\text { Hepatit }\end{array}$ & $\begin{array}{c}\text { Peptik } \\
\text { Ülser }\end{array}$ & $\begin{array}{c}\text { Karaciğer } \\
\text { H. }\end{array}$ & \multicolumn{2}{|c|}{ Viral Hepatit+ Karaciğer } & Diğer & Toplam & $\mathbf{P}$ \\
\hline \multirow{2}{*}{\multicolumn{2}{|c|}{ KADIN }} & $\mathbf{n}$ & 35 & 8 & 4 & \multicolumn{2}{|c|}{2} & 13 & 62 & \multirow[b]{4}{*}{$>0,05$} \\
\hline & & $\%$ & 0,87 & 0,16 & 0,08 & & & 0,3 & 1,45 & \\
\hline \multirow{2}{*}{\multicolumn{2}{|c|}{ ERKEK }} & $\mathbf{n}$ & 37 & 2 & 1 & \multicolumn{2}{|c|}{$\frac{0,04}{3}$} & 13 & 56 & \\
\hline & & $\%$ & 0,93 & 0,04 & 0,02 & \multicolumn{2}{|c|}{0,06} & 0,3 & 1,05 & \\
\hline \multirow{2}{*}{\multicolumn{2}{|c|}{ CINNSİYET }} & \multicolumn{4}{|c|}{ SOLUNUM SISTEMI (a) } & \multicolumn{4}{|c|}{ KAN HASTALIKLARI (b) } & $\mathbf{P}$ \\
\hline & & KOAH\#\# & Astım & Diğgr & Toplam & Anemi & Lösemi & Diğer & Toplam & (a) \\
\hline \multirow{2}{*}{ KADIN } & $\mathbf{n}$ & 76 & 2 & 2 & 80 & 14 & 2 & 21 & 37 & $=0,00$ \\
\hline & $\%$ & 1,86 & 0,05 & 0,05 & 1,96 & 0,32 & 0,04 & 0,52 & 0,88 & \multirow{3}{*}{$\begin{array}{c}\text { (b) } \\
<0,05\end{array}$} \\
\hline \multirow{2}{*}{ ERKEK } & $\mathbf{n}$ & 30 & 9 & 2 & 41 & 3 & 3 & 7 & 13 & \\
\hline & $\%$ & 0,74 & 0,25 & 0,05 & 1,4 & 0,08 & 0,06 & 0,18 & 0,32 & \\
\hline
\end{tabular}

Tablo 3b. Sistemik hastalıkların cinsiyetlere göre alt gruplarına dağılımları (devamı)

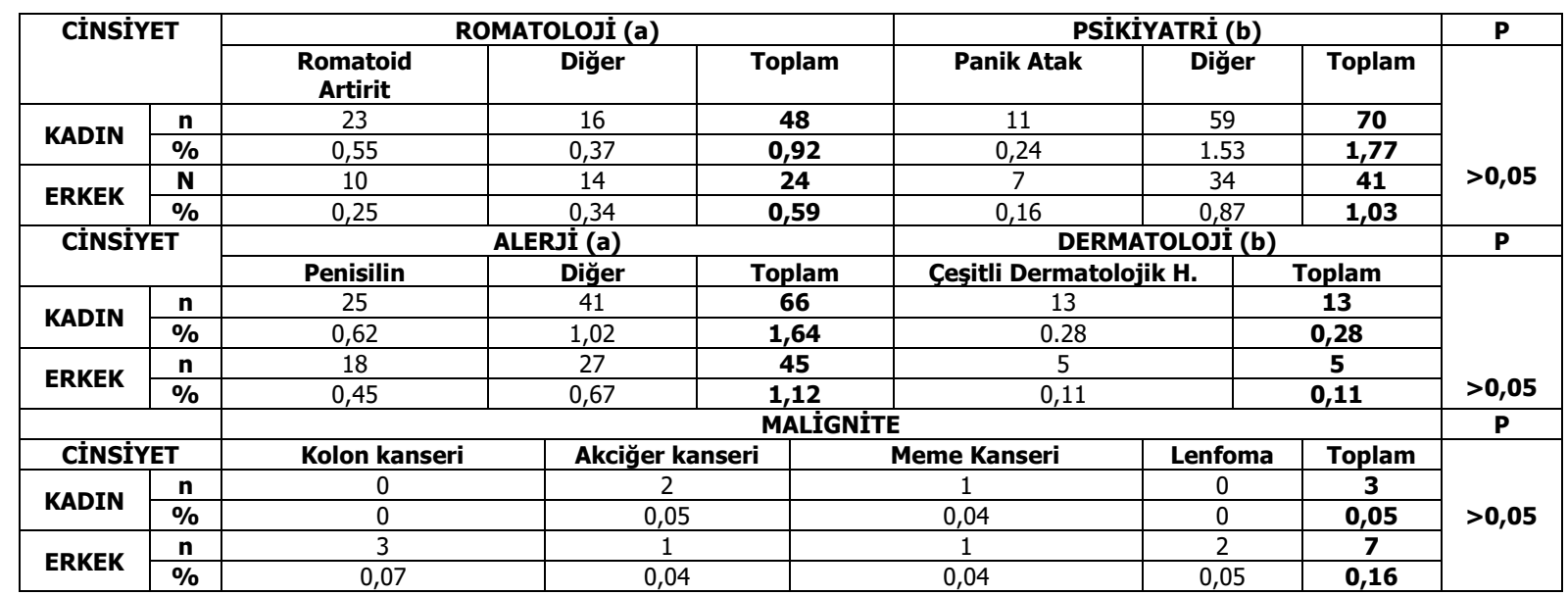


Tablo 4a. Sistemik hastalıkların yaş gruplarına göre alt gruplarına dağılımları

\begin{tabular}{|c|c|c|c|c|c|c|c|c|c|c|c|c|}
\hline \multicolumn{13}{|c|}{ KARDİYOVASKÜLER SİSTEM } \\
\hline \multicolumn{2}{|c|}{ YAŞ GRUPLARI } & HT* & KDH* & \multicolumn{2}{|c|}{ KKH*** } & \multirow{2}{*}{\multicolumn{2}{|c|}{$\begin{array}{c}\text { Diğer } \\
4\end{array}$}} & \multicolumn{2}{|c|}{ HT+ Diğer } & HT+KDH & Toplam & $\mathbf{P}$ \\
\hline \multirow[t]{2}{*}{$<18$} & $\mathbf{n}$ & 1 & 2 & \multicolumn{2}{|r|}{1} & & & \multicolumn{2}{|r|}{-} & - & 8 & \multirow{8}{*}{$=0.00$} \\
\hline & $\%$ & 0,04 & 0,05 & & 0,04 & \multicolumn{2}{|c|}{0,1} & \multicolumn{2}{|r|}{0} & 0 & 0,23 & \\
\hline \multirow[t]{2}{*}{$18-40$} & $n$ & 27 & 6 & & 16 & \multicolumn{2}{|c|}{13} & & 2 & 2 & 66 & \\
\hline & $\%$ & 0,7 & 0,15 & & 0,4 & \multicolumn{2}{|c|}{0,3} & \multicolumn{2}{|r|}{$<05$} & 0,05 & 1,65 & \\
\hline \multirow[t]{2}{*}{ 41-65 } & $n$ & 150 & 28 & & 4 & \multicolumn{2}{|c|}{22} & \multicolumn{2}{|r|}{11} & 9 & 224 & \\
\hline & $\%$ & 3,7 & 0,7 & & 0,1 & \multicolumn{2}{|c|}{0,5} & \multicolumn{2}{|r|}{0,3} & 0,2 & 5,5 & \\
\hline \multirow[t]{2}{*}{$>65$} & $\mathbf{n}$ & 50 & 10 & & 1 & \multicolumn{2}{|c|}{5} & \multicolumn{2}{|r|}{10} & 4 & 80 & \\
\hline & $\%$ & 1,2 & 0,25 & & 04 & & & & 0,25 & 0,1 & 1,96 & \\
\hline & & & & & & İN & STE & & & & & \\
\hline YAŞ GR & ARI & DM\# & & roid Bezi H. & DM & & & Tiroi & Bezi & Diğer & Toplam & $\mathbf{P}$ \\
\hline$<18$ & $\mathbf{n}$ & 5 & & 2 & & & & 0 & & 2 & 9 & \\
\hline & $\%$ & 0,12 & & 0,05 & & & & 0 & & 0,05 & 0,22 & \\
\hline $18-40$ & $n$ & 28 & & 39 & & & & 3 & & 1 & 77 & \\
\hline & $\%$ & 0,7 & & 1 & & & & 0,07 & & 0,04 & 1,96 & \\
\hline 41-65 & $\mathrm{n}$ & 108 & & 45 & & & & 15 & & 5 & 207 & $=0.00$ \\
\hline & $\%$ & 2,7 & & 1,2 & & & & 0,4 & & 0,12 & 4,47 & \\
\hline$>65$ & $n$ & 29 & & 5 & & & & 5 & & 1 & 41 & \\
\hline & $\%$ & 0,7 & & 0,12 & & & & 0,12 & & 0,04 & 1,04 & \\
\hline & & & SOLUN & NUM SİSTEI & I (a) & & & & KANHAST & IKLARI (b) & & $\mathbf{P}$ \\
\hline YAŞ GR & ARI & KOAH & Astım & Diğer & & & & & Lösemi & Diğer & Toplam & \\
\hline$<18$ & $n$ & 0 & 2 & 0 & & & & & 0 & 0 & 0 & \\
\hline & $\%$ & 0 & 0,05 & 0 & & & & & 0 & 0 & 0 & \\
\hline $18-40$ & $n$ & 3 & 39 & 2 & & & & & 3 & 19 & 31 & \\
\hline & $\%$ & 0,07 & 0,9 & 0,05 & & & & & 0,07 & 0,5 & 0,8 & \\
\hline 41-65 & $n$ & 6 & 57 & 2 & & & & & 1 & $\frac{1}{8}$ & 16 & $=0.00$ \\
\hline & $\%$ & 0,15 & 1,4 & 0,05 & & & & & 0,04 & 0,2 & 0,44 & \\
\hline$>65$ & $n$ & 2 & 8 & 0 & & & & & 1 & 1 & 3 & \\
\hline & $\%$ & 0,05 & 0,2 & 0 & & & & & 0,04 & 0,04 & 0,12 & \\
\hline
\end{tabular}

Tablo 4b. Sistemik hastalıkların yaş gruplarına göre alt gruplarına dağılımları (devamı)

\begin{tabular}{|c|c|c|c|c|c|c|c|c|c|c|}
\hline \multirow{2}{*}{\multicolumn{2}{|c|}{ YAŞ GRUPLARI }} & \multicolumn{4}{|c|}{ ROMATOLOJİ (a) } & \multicolumn{4}{|c|}{ PSİKİYATRİ (b) } & $\mathbf{P}$ \\
\hline & & \multirow{2}{*}{\multicolumn{2}{|c|}{$\begin{array}{c}\text { Romatoid Artirit } \\
1\end{array}$}} & \multirow{2}{*}{$\frac{\text { Diğer }}{2}$} & \multirow{2}{*}{$\begin{array}{c}\text { Toplam } \\
3\end{array}$} & \multirow{2}{*}{\multicolumn{2}{|c|}{$\frac{\text { Panik Atak }}{2}$}} & \multirow{2}{*}{$\frac{\text { Diğer }}{8}$} & \multirow{2}{*}{\begin{tabular}{|c|} 
Toplam \\
10
\end{tabular}} & \multirow{9}{*}{$\begin{array}{c}(a) \\
<0,005\end{array}$} \\
\hline \multirow[t]{2}{*}{$<18$} & $\mathbf{n}$ & & & & & & & & & \\
\hline & $\%$ & \multicolumn{2}{|c|}{0,04} & 0,05 & 0,09 & \multicolumn{2}{|c|}{0,05} & 0,2 & 0,25 & \\
\hline \multirow[t]{2}{*}{$18-40$} & $\mathbf{n}$ & \multirow{2}{*}{\multicolumn{2}{|c|}{$\frac{15}{0.4}$}} & \multirow{2}{*}{9} & 24 & \multicolumn{2}{|l|}{9} & 49 & 58 & \\
\hline & $\%$ & & & & 0,6 & 0,2 & & 1,2 & 1,4 & \\
\hline \multirow[t]{2}{*}{ 41-65 } & $\mathrm{n}$ & \multicolumn{2}{|l|}{$\frac{0,4}{14}$} & 15 & 29 & \multirow{2}{*}{\multicolumn{2}{|c|}{15}} & 29 & 35 & \\
\hline & $\%$ & \multicolumn{2}{|l|}{0,3} & 0,4 & 0,7 & & & 0,72 & 0,87 & \\
\hline \multirow[t]{2}{*}{$>65$} & $\mathbf{n}$ & \multicolumn{2}{|l|}{3} & \multirow{2}{*}{$\begin{array}{c}4 \\
0,1\end{array}$} & 7 & \multirow{2}{*}{\multicolumn{2}{|c|}{$\begin{array}{c}4 \\
0,1\end{array}$}} & 6 & 8 & \\
\hline & $\%$ & \multicolumn{2}{|c|}{0,09} & & 0,19 & & & 0,15 & 0,2 & \\
\hline YACGD & ADT & & ALER & & & & RMATO & OJİ (b) & & $\mathbf{P}$ \\
\hline YAŞ GR & LARI & Penisilin & & ğer & Toplam & Çeşitl & matolo & ik H. & Toplam & \\
\hline$<18$ & $\mathbf{n}$ & 4 & & 2 & 16 & & 2 & & 2 & (a) \\
\hline & $\%$ & 0,1 & & 3 & 0,4 & & 05 & & 0,05 & $>0,05$ \\
\hline $18-40$ & $\mathbf{n}$ & 21 & & 6 & 56 & & 9 & & 9 & \\
\hline & $\%$ & 0,5 & & 9 & 1,4 & & 0,2 & & 0,2 & \\
\hline 41-65 & $\mathbf{n}$ & 18 & & 6 & 34 & & 6 & & 6 & (b) \\
\hline & $\%$ & 0,45 & & 4 & 0,85 & & 15 & & 0,15 & $>0,05$ \\
\hline$>65$ & $\mathbf{n}$ & 0 & & 4 & 4 & & 1 & & 1 & \\
\hline & $\%$ & 0 & & 1 & 0,1 & & ,04 & & 0,04 & \\
\hline & & & & & MALIGNİTE & & & & & \\
\hline YAŞ GR & LARI & Kolon ka & & Akci & kanseri & Meme 1 & & Lenfoma & Toplam & $\mathbf{P}$ \\
\hline$<18$ & $\mathbf{n}$ & 0 & 0 & 0 & 0 & 0 & 0 & 0 & 0 & \\
\hline & $\%$ & 0 & 0 & 0 & 0 & 0 & 0 & 0 & 0 & \\
\hline $18-40$ & $\mathbf{n}$ & 1 & 1 & 0 & 0 & 2 & 1 & 1 & 0 & \\
\hline & $\%$ & 0,04 & 0,04 & 0 & 0 & 0,08 & 0,04 & 0,04 & 0 & $<0,005$ \\
\hline 41-65 & $n$ & 1 & 2 & 1 & 0 & 4 & 1 & 2 & 1 & \\
\hline & $\%$ & 0,04 & 0,08 & 0,04 & 0 & 0,16 & 0,04 & 0,08 & 0,04 & \\
\hline$>65$ & $n$ & 1 & 0 & 1 & 2 & 4 & 1 & 0 & 1 & \\
\hline & $\%$ & 0,04 & 0 & 0,04 & 0,08 & 0,16 & 0,04 & 0 & 0,04 & \\
\hline
\end{tabular}




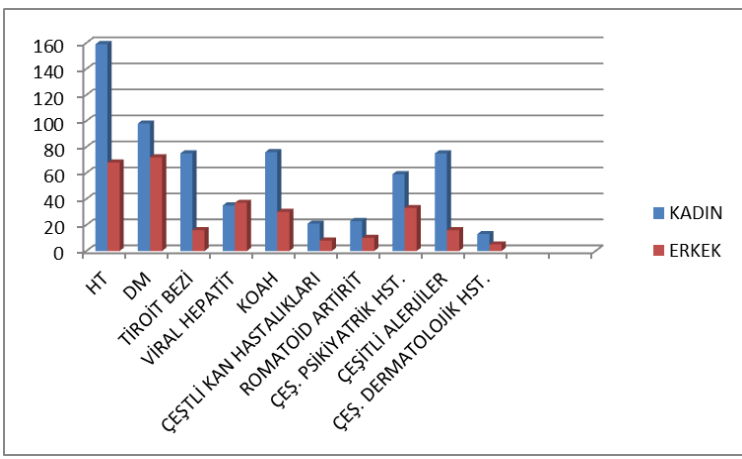

Grafik 1. Sistemik hastalıkların cinsiyetlere göre dağılımı

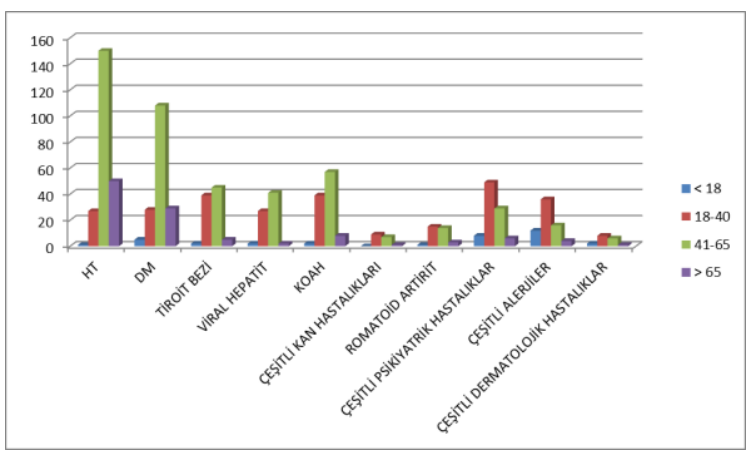

Grafik 2. Sistemik hastalıkların yaş gruplarına göre dağılımı

\section{TARTIŞMA}

Olası komplikasyonları önüne geçebilmek için diş hekimlerine tedavi amacıyla başvuranlarda var olabilecek hastalıkların öğrenilmesi büyük önem taşımaktadır. Diş tedavisi için başvuranların sistemik hastalık profillerini ortaya koymaya yönelik pek çok çalışma yapılmıştır. Bu çalışmalarda çok farklı sonuçların ortaya çıktığı görülmektedir. Sistemik hastalıkların görülmesi ile ilgili olarak Cottone ve arkadaşları $^{7} \% 68,5$ gibi yüksek bir oran verirken, Rhodus ve arkadaşları $^{8} 1976$ yılı çalışmalarında $\% 7,3^{\prime}$ lük, 1986 yılı çalışılmalarında ise \%24,6'ık bir oran bulduklarını belirtmişlerdir. Saengsirinavin ve arkadaşları $^{9} \% 55,45$, Umino ve arkadaşları $^{10} \% 64,2$, Smeets ve arkadaşlar $^{11} \% 28,2$, Dhanuthai ve arkadaşları da ${ }^{12} \% 12,2$ gibi bir oran vermişlerdir. Ülkemizde ise Aydıntuğ ve arkadaşları ${ }^{13}$, \%39,50 gibi bir sistemik hastalık oranı verirken, Hatipoğlu ve arkadaşları $^{14} \% 39,1$, Göktürk ve arkadaşları ${ }^{15}$ ise $\% 13,8$ oranda sistemik hastalıkların görüldüğünü belirtmişlerdir. Çalışmamızın sonuçları ise \%32,02'lik bir oran ortaya koymuştur. Bu birbirinden çok farklı oranların görülmesinin, çalışmalara dâhil edilen bireylerin sayılarının ve yaş gruplarının farklı oluşu gibi nedenlere bağlı olduğu düşünülmektedir. Ayrıca sistemik hastalıklarla ilgili bilgi toplama yöntemlerindeki farklılıklar, hastaların bilinç düzeylerinin yeterli olup olmaması, sorulan sorulara tutarlı yanit verip vermemelerinin de sonuçlar üzerinde etkili olduğu unutulmamalıdır. Kişisel deneyimimiz, bazı hastalıkların hastalar tarafından beyan edilmediğini göstermektedir. Bunda bazı hastalıkların kişiler tarafından önemli kabul edilmemesinin yanında, dental tedavinin ertelenmesine neden olabileceği düşüncesiyle saklanmaları da etkili olmaktadır. Bu da sistemik hastalık anamnezinin daha dikkatli alınması, gerektiğinde kullanılan ilaçların da sorularak istenilen bilgilere ulaşılmasının gerekliliğini ortaya koymaktadır.

Sağlık kuruluşlarına ulaşabilme olanaklarının artması ve tıbbi teknolojilerin gelişmesine bağlı olarak tedavi edilebilirliğin gelişmesi, yaşam süresinin uzamasına neden olmuştur. Tıptaki bu gelişmeler diş hekimliğinde de kendini göstermiş, ağızında daha fazla sayıda doğal dişi olan yaşlı kişi sayısında artış olmuştur. Bu da diş hekimliği tedavisine başvuran, ileri yaşta ve sağlık sorunları olan birey sayısının artmasıyla anlamına gelir. ${ }^{12}$ Diş tedavisi gereksinimi olan bireylerde var olabilecek hastalıkların neler olabileceği ile ilgili olarak da çok çeşitli çalışmalar yapılmıştır. Bu çalışmaların sonuçları da insidans çalışmalarında olduğu gibi farklılıklar göstermektedir. Çalışmamızın sonuçları bunların bazılarıyla benzerlikler, bazılarıyla da farklılıklar ortaya koydu. Çalışmamızda olduğu gibi Al-

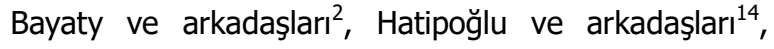
Başlarlı ve arkadaşları ${ }^{16}$, Lagervall ve arkadaşları ${ }^{17}$ ve Dumitrescu $^{18}$ en fazla hipertansiyon ile karşılaşıldığını belirtmişlerdir. Aydıntuğ ve arkadaşları ${ }^{13}$ ve Göktürk ve arkadaşları $^{15}$ ise kardiyovasküler hastalıkların ilk sırada yer aldığını ifade etmişlerdir. Burada kardiyovasküler sistem hastalıkların neler olduğu açık olarak belirtilmediği için, hipertansiyonun bu başlık altında sınıflandırıldığı düşünülmektedir. Kömerik ve Çadır ${ }^{19}$ ise konsültasyon formları üzerinden yürüttükleri çalışmalarında, en fazla konsültasyonun kardiyolojik hastalıklar için istendiğini, bunda da hipertansiyonun 3. sırada yer aldığını belirtmişlerdir. Çalışmamızda en sık rastlanan 2. hastalık olan diyabet ise Kömerik ve Çadır $^{19 ı}$ ın çalışmasında daha az rastlanan bir hastalık olarak belirtilmiştir. Almas ve Awartani'nin ${ }^{1}$

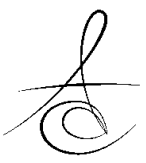


çalışmasında ise diyabet en fazla görülen hastalıktı. Lagervall ve arkadaşlarının ${ }^{17}$ ve Dhanuthai ve arkadaşlarının $^{12}$ çalışmalarında en sık karşılaşılan hastalık olan alerji, çalışmamızda 5. sırada yer almaktaydı. Ayrıca Hatipoğlu ve arkadaşları ${ }^{14}$ tiroit bezi hastalıklarının hipertansiyonla aynı oranda görüldüğünü belirtmişlerdir. Çalışmamızda ise tiroit bezi hastalıkları, daha az rastlanan hastalıklardandı. Hipertansiyon üzerine Türkiye'de Altun ve arkadaşlarının $^{20} 4910$ hasta üzerinde yaptıkları çok merkezli kesitsel çalışma, hipertansiyonun kadınlarda daha fazla görüldüğünü ortaya çıkarmıştır. Yaş ilerledikçe sıklık da artmaktaydı. Bu sonuçlarla uyumlu olacak şekilde çalışmamızda da hipertansiyon olduğunu beyan eden kadınların oranı, erkeklerden daha fazla idi. Ayrıca orta yaş grubunda hipertansiyon görülme oranı daha da artıyordu. Onat ve arkadaşlarının $^{21} 3401$ kişi üzerinde yaptıkları çalışma, Türkiye'de diyabetes mellitus insidansının 35 yaş ve üstü bireylerde yaklaşık olarak \%11 olduğunu, kadınlarda da daha fazla rastlandığını ortaya koymuştur. Çalışmamızda da benzer şekilde diyabetes mellitusa orta yaş grubunda ve kadınlarda daha fazla rastlandığı görüldü.

Sonuç olarak; Çalışmamızın sonuçları hipertansiyon, diyabet, $\mathrm{KOAH}$, psikiyatrik hastalıklar, tiroit bezi hastalıkları ve viral hepatitin kadınlarda daha fazla görüldüğünü ortaya koydu. Erkeklerde ise yalnızca viral hepatitin kadınlardan daha fazla görüldüğü anlaşıldı. Çalışmamızda da olduğu gibi, geri dönüp inceleme yapılabilmesi için hasta kayıtlarının düzenli tutulmasının büyük önemi vardır. Ayrıca sistemik hastalıklarla ilgili bilgi düzeylerinin artması için diş hekimliği öğrencilerinin eğitimlerinin yeniden düzenlenmesinin gerekliliği de unutulmaması gereken bir konudur.

Emin Murat Canger: ORCID ID: 0000-0002-0798-9355 Şifa Tatlı: ORCID ID: 0000-0003-2593-5526

\section{KAYNAKLAR}

1. Almas K, Awartani FA. Prevalance of medically compromised patients referred for periodontal treatment to a teaching hospital in central Saudi Arabia. Saudi Med J;24:1242-5.
2. Al-Bayaty HE, Murti PR, Naidu RS, Matthews R, Simeon D. Medical problems among dental patients at the school of dentistry, The University of the West Indies. J Dent Educ 2009;73:140814.

3. Oto A. Hikaye Alma. In : Hikaye Alma ve Fiziki Muayene. Ed. Kansu E, Oto A, Oktay A. 1. Baskı. Ankara; Hacettepe Üniversitesi Yayınları: 1989. p. 1-43.

4. Özcan İ, Şirin Ş. Oral Diagnoza Giriş. Sistemik Yaklaşımlarla Oral Diagnoz. Özcan İ, editör. 1. Baskı. İstanbul; Nobel tıp Kitabevleri: 2007. p. 73-82.

5. Kınoğlu T, Akhunlar M, Alasya D, Kulu FŞ. Diş Hekimliğinde Sistemik Hastalıklar. G.Ü Dişhek Fak Der 1986;III:115-9.

6. Radfar L.,Suresh L. Medical profile of a dental school patient population. J Dent Educ 2007;71:682-6.

7. Cottone JA, Kafrawy AH. Medications and health histories: a survey of 4,365 dantel patients. J Am DentAssoc1979;98:713-8.

8. Rhodus NL, Bakdash MB, Little JW, Haider ML. Implications of the changing medical profile of a dantel school patient population. JAm Dent Assoc 1989;119:414-6.

9. Saengsirinavin C, Kraivaphan P, Phumara P. Survey of drugs and medical history among denta lout-patients. J Dent Assoc Thai 1990;40: 68-74.

10. Umino M, Nagao M. Systemic diseases in elderly dental patients. Int Dent J 1993;43:213-8.

11. Smeets EC, De Jong KJ, Abraham-Inpijn L. Detecting themedically compromised patient in dentistry by means of the medical risk related history. A survey of 29,424 dental patients in The Netherlands. PrevMed.1998;27:530-5.

12. Dhanuthai K, Sappayatosok K, Bijaphala P, Kulvitit $\mathrm{S}$, Sereerat T. Prevalence of medically compromised conditions in dental patients. Med Oral Patol Oral Cir Bucal. 2009;14:E287-91.

13. Aydıntuğ YS, Şençimen M, Bayar G R, Mutlu İ, Gülses A. Ağız, diş, çene hastalıkları ve cerrahisi polikliniğine başvuran erişkin hastalarda çeşitli sistemik hastalıkların görülme sıklıkları. Gülhane Tıp Dergisi 2010;52:7-10. 
14. Hatipoğlu MG, Hatipoğlu H, Pekkan G. Bir üniversite hastanesi diş hekimliği birimine başvuran hastaların anamnez formlarının değerlendirilmesi. Balıkesir Sağlık Bilimleri Dergisi 2012;1:54-8.

15. Göktürk Ö, Göktürk H. Amasya Ağız ve Diş sağlığı Merkezi'ne başvuran başvuran hastaların endodontik, periodontal tedavi gereksinimlerine göre araştırılması. Atatürk Üniv. Diş Hek. Fak. Derg. J Dent Fac Atatürk Uni.2014;24:360-6.

16. Başlarlı Ö, Adiloğlu I, Taşar F, Tümer C, Saysel MY. Medical profile of a dental school patient population. Clinical Dentistry and Research 2014; 38:28-35.

17. Lagervall M, Jansson L, Bergström J. Systemic disorders in patients with periodontal disease. J Clin Periodontol.2003;30:293-9.

18. Dumitrescu AL. Occurance of self-reported systemic medical conditions in patients with periodontal disease. Romanian Journal of InternalMedicine.2006;44:35-48.

19. Kömerik N, Çadır B. Ağız cerrahisi tarafından istenen konsültasyon formlarının analizi. Tıp ve diş hekimliği iletişimi inmal edilmiş bir ayrıntı mı? GÜ Diş Hek Fak Derg 2004;21:205-8.

20. Altun B, ArıCı M, Nergizoğlu G, Derici U, Karatan O, Turgan C, Sindel S, Erbay B, Hasanoğlu E, Cağlar S; Turkish Society of Hypertension and Renal Diseases. Prevalence, awareness, treatment and control of hypertension in Turkey (the PatenT study) in 2003. J Hypertens 2005; 23:1817-23.

21. Onat A, Hergenç G, Uyarel H, Can G, Özhan H. Prevalence, incidence, predictors and outcome of type 2 diabetes in Turkey. Anadolu Kardiyoloji Derg 2006;6:314-21.

\section{Yazışma Adresi}

Doç. Dr. Emin Murat CANGER

Erciyes Üniversitesi Diş Hekimliği Fakültesi Ağız

, Diş ve Çene Radyolojisi AD

Melikgazi-38059- KAYSERİ

Telefon: 035220766 66-29225

Faks: 03524380657

Email: emcanger@erciyes.edu.tr 